\title{
Association study of the angiotensin-converting enzyme (ACE) gene G2350A dimorphism with myocardial infarction
}

\author{
M. Perwaiz $|q b a|^{1,3}$, Saeed Mahmood ${ }^{1}$ \\ Naseema Mehboobali ${ }^{1}$, Mohammad Ishaq ${ }^{2}$ \\ Tasnim Fatima ${ }^{1}$, Saddiqa Parveen ${ }^{1}$ \\ and Philippe Frossard ${ }^{1}$ \\ ${ }^{1}$ Department of Biological and \\ Biomedical Sciences \\ Faculty of Health Sciences \\ The Aga Khan University \\ Karachi-74800, Pakistan \\ ${ }^{2}$ National Institute of Cardiovascular Diseases \\ Karachi, Pakistan \\ ${ }^{3}$ Corresponding author: Tel, 92-21-493-0051; \\ Fax, 92-21-493-4294; E-mail, perwaiz.iqbal@aku.edu
}

Accepted 1 December 2003

Abbreviations: $A C E$, angiotensin-converting enzyme; $A M I$, acute myocardial infarction; BMI, body mass index; CVD, cardiovascular disease; df, degrees of freedom; I/D, insertion/deletion; IHD, ischemic heart disease; LD, linkage disequilibrium; QTL, quantitative trait locus

\section{Abstract}

The angiotensin converting enzyme (ACE) is a strong candidate gene for myocardial infarction (MI). Insertion-deletion dimorphism in intron 16 of this gene has been inconclusively found to be associated with it. Several new polymorphisms in the ACE gene have been identified and among these, a dimorphism in exon 17, ACE G2350A, has a significant effect on plasma ACE concentrations. To assess the value of genotyping the $A C E$ G2350A dimorphism in a genetically homogeneous population, we carried out a case-control study of dimorphism G2350A for a putative association with MI among Pakistani nationals. We investigated a sample population of 370 Pakistanis, comprising 163 controls, and 207 patients with clinical diagnosis of acute MI (AMI). ACE G2350A alleles were visualized by assays based on polymerase chain reaction and restriction endonuclease analysis. Frequencies of $\mathbf{G}$ alleles were 0.68 among controls and 0.72 among $A M I$ patients. The ACE G2350A dimorphism showed no significant association with $\mathrm{MI}\left(\chi^{2}=0.90,2 \mathrm{df}, P=0.64\right)$, plasma levels of homocysteine $(P=0.52)$ or with serum levels of folate $(P=0.299)$. The results indicate that ACE G2350A polymorphism is not associated with risk of myocardial infarction in the Pakistani population investigated here.

Keywords: angiotensin converting enzyme; folic acid; genetics; homocysteine; myocardial infarction; Pakistani population

\section{Introduction}

Angiotensin converting enzyme (ACE) is a dipeptidyl carboxypeptidase I, (EC. 3.4.15.1) that activates angiotensin I through cleavage of the carboxyterminal dipeptide into the potent vasoconstrictor angiotensin II and inactivates the vasodilator peptide bradykinin (Erdös and Skidgel, 1987). Both are mediators of vascular tone and smooth muscle cell proliferation (Ehlers and Riordan, 1989). Experimental data suggest that the presence of high levels of plasma ACE could result in the thickening of the vascular wall eventually leading to the development of vascular disease (Erdös and Skidgel, 1987; Ehlers and Riordan, 1989).

Circulating ACE levels show extensive inter- individual variability and are highly genetically determined (Cambian et al., 1988; Alhenc-Gelas et al., 1991). An insertion/deletion (I/D) dimorphism, due to the presence or absence of a 287 base pair (bp) alu-type sequence in intron 16 of the ACE gene, has been shown to cosegregate with serum and tissue ACE activities, and major locus inheritance explains best the findings that the $D$ allele is associated with elevated ACE levels (Cambian et al., 1988; Rigat et al., 1990; Alhenc-Gelas et al., 1991). Thus, the ACE gene is viewed as a quantitative trait locus (QTL) that modulates circulating ACE levels, and the ACE I/D dimorphism is a marker that is thought to be in linkage disequilibrium (LD) with functional variants located in the ACE gene (Cambian et al., 1992; Tiret et al., 1992; Arca et al., 1998) that are implicated in CVDs.

Several studies on the association of ACE I/D polymorphism and the risk for myocardial infarction (MI) (Bohn et al., 1993; Cambien et al., 1994; Evans et al., 1994; Soubrier and Cambien, 1994; Cambian and Evans, 1995; Lindpainter et al., 1995; Villard and Soubrier, 1996; Ferrieres et al., 1999; O' Mally et al., 1999; Keavney et al., 2000), have generated incon- 
sistent information. This has stimulated a search for new polymorphisms in the $A C E$ gene to identify better markers or actual functional variants. Accumulated evidence points to the existence of two QTLs at this chromosomal locus (McKenzie et al., 1995; Villard et al., 1996; Zhu et al., 2000; McKenzie et al., 2001). A genome-scan analysis by The Framingham Heart Study found strong evidence for a QTL on chromosome 17, located close to the ACE gene and linked to blood pressure (Levy et al., 2000). Amongst the 13 polymorphisms of the ACE gene recently reported, a dimorphism in exon 17, ACE G2350A, has the most significant effect on plasma ACE concentrations (Zhu et al., 2001). After adjustment for the effect of ACE G2350A dimorphism, the I/D dimorphism was no longer associated with $A C E$, indicating that it is in LD with ACE G2350A and unlikely to be a functional mutation (Zhu et al., 2001).

To assess the value of genotyping of ACE in Pakistani population, we carried out a case-control study of dimorphism G2350A for a putative association with $\mathrm{MI}$ and with plasma/serum levels of homocysteine and folate amongst Pakistani nationals. Our study is aimed at establishing whether the ACE G2350A dimorphism is a genetic marker and an independent risk factor for MI.

\section{Materials and Methods}

\section{Study subjects}

Two hundred and seven consecutive Pakistani patients with acute MI (AMI) (age, 30-70 years) admitted to the National Institute of Cardiovascular Diseases (NICVD), Karachi from January 2001 to June 2001, were selected for this study. They had confirmed diagnosis of AMI on the basis of clinical history, ECG and biochemical data.

Similarly, 163 normal healthy subjects who had been matched for sex and to some extent for age and belonged to the same socio-economic class, were selected from the personnel of the Aga Khan University and Civil Hospital, Karachi for this study. Informed consent was obtained from the participants and the study was approved by the Ethical Committee of the Aga Khan University.

A stringent criteria was used for the selection of normal healthy control subjects. In addition to being matched for age, sex and socioeconomic background, they had no evidence of CAD, diabetes mellitus, hypertension, obesity and hypercholesterolemia. Those control subjects who were found to be pregnant, using antiepileptics, oral contraceptives, having malabosorption syndrome, suffering from tuberculosis, uremia, liver disease, or using B-complex vitamins during the last six months were excluded from this study.

\section{DNA analysis}

Blood was collected in $10 \mathrm{~m}$; Na-EDTA tubes and kept frozen at $-20^{\circ} \mathrm{C}$. DNA was extracted using standard protocols (Sambrook et al., 1989) and stored in $10 \mathrm{mM}$ Tris- $\mathrm{HCl}, 1 \mathrm{mM}$ EDTA, $\mathrm{pH}$ 8.0.

Codon 2350 ACE genotypes were first visualized by a method based on allele-specific oligonucleotides (McKenzie et al., 1995). It was then described as ACE-8 by Zhu et al. (2001), as a modification by introducing a mismatch guanine at the $3^{\prime}$ end of the primer sequence, resulting in the amplification of a BstU1 restriction site. This more convenient method involves a set of primers designed to amplify a 122-bp fragment encompassing the polymorphic region of ACE gene: 5'-CTGACGAATGTGATGGCCGC 3' (upstream) and 5'-TTGATGAGTTCCACGTATTTCG-3' (downstream). The PCR contained 100 to $200 \mathrm{ng}$ DNA template, $125 \mu \mathrm{M}$ dNTPs, $2.5 \mathrm{mM} \mathrm{MgCl}_{2}$, and $0.3 \mathrm{mM}$ of each primer and $1 \mathrm{U}$ Taq polymerase, in a final volume of $10 \mu \mathrm{l}$. After initial denaturation at $95^{\circ} \mathrm{C}$ for $5 \mathrm{~min}, \mathrm{PCR}$ was carried out for 35 cycles, each one comprised of denaturation at $94^{\circ} \mathrm{C}$ for 30 $\mathrm{s}$, annealing at $58^{\circ} \mathrm{C}$ for $30 \mathrm{~s}$, and extension at $72^{\circ} \mathrm{C}$ for $30 \mathrm{~s}$, with a final extension time of $10 \mathrm{~min}$ at $72^{\circ} \mathrm{C}$. PCR products $(5 \mu \mathrm{l})$ were digested with $5 \mathrm{U}$ of BstUl (Life Technologies) at $60^{\circ} \mathrm{C}$ for $2 \mathrm{~h}$. Digested fragments were separated by electrophoresis on $3 \%$ agarose gel and identified by ethidium bromide staining. Allele G2350 was visualized as a 122-bp fragment and allele A2350 as 100-bp and 22-bp fragments.

\section{Data analysis}

Statistical analyses were done with the help of an SPSS ${ }^{\circledR}$ version 10.0 for Windows ${ }^{\circledR}$ software package (Gorinchem, The Netherlands). Distribution differences of G/A 2350 genotypes in the patients (AMI) as compared to distribution in the control group as well as Hardy-Weinberg proportions of allele distribution were assessed by chi-square analyses on $3 \times 2$ tables. Means were compared using ANOVA. For all analyses, statistical significance was considered when significance level $(P)$ values were lower than 0.05 .

\section{Results}

Demographic and clinical characteristics of patients have been listed in Table 1. The patient group comprised 51 females and 156 males, showing a female to male ration of $1: 3$. The mean age was $53 \pm$ 9.6 years (range $30-70$ years) in this group. Mean body mass index (BMI) was $24 \pm 5.6$, while mean serum glucose concentration was $144 \pm 72 \mathrm{mg} / \mathrm{dl}$. Mean cholesterol concentration was $185 \pm 45 \mathrm{mg} / \mathrm{dl}$. $43 \%$ of them were smokers, $31 \%$ were hypertensive, 
Table 1. Demographic and Clinical Characteristics of Subjects. (Mean \pm S.D)

\begin{tabular}{|c|c|c|c|c|}
\hline & \multicolumn{2}{|c|}{ Controls $(n=163)$} & \multicolumn{2}{|c|}{ Patients $(n=207)$} \\
\hline & Values & Frequency (\%) & Values & Frequency $(\%)$ \\
\hline Age (Years) & $49.3 \pm 9.6$ & & $53 \pm 9.6$ & \\
\hline $\begin{aligned} \text { Gender } & \text { (Male) } \\
& \text { (Female) }\end{aligned}$ & & $\begin{array}{rr}123 & (75.5) \\
40 & (24.5)\end{array}$ & & $\begin{aligned} 156 & (75.4) \\
51 & (24.6)\end{aligned}$ \\
\hline Body mass index $\left(\mathrm{kg} / \mathrm{m}^{2}\right)$ & $24.0 \pm 5.6$ & & $24.5 \pm 3.6$ & \\
\hline Glucose (mg/dl) & $100 \pm 24$ & & $144 \pm 72^{*}$ & \\
\hline Cholesterol (mg/dl) & $168 \pm 34$ & & $185 \pm 45^{*}$ & \\
\hline $\begin{aligned} \text { Smoking status } & \text { (smokers) } \\
& \text { (non-smokers) }\end{aligned}$ & & $\begin{array}{l}17 \\
83\end{array}$ & & $\begin{array}{l}43^{*} \\
57\end{array}$ \\
\hline $\begin{array}{l}\text { Diet } \text { (vegetarian) } \\
\text { (non-vegetarian) }\end{array}$ & & $\begin{array}{r}3 \\
97\end{array}$ & & $\begin{array}{r}1 \\
99\end{array}$ \\
\hline $\begin{array}{r}\text { Parental History of IHD (Yes) } \\
\text { (No) }\end{array}$ & & 15 & 85 & $\begin{array}{l}26^{*} \\
74\end{array}$ \\
\hline $\begin{aligned} \text { Hypertension } & \text { (Yes) } \\
& (\mathrm{No})\end{aligned}$ & & $\begin{array}{r}0 \\
100\end{array}$ & & $\begin{array}{l}31 \\
69\end{array}$ \\
\hline $\begin{aligned} \text { Diabetes } & \text { (Yes) } \\
& (\mathrm{No})\end{aligned}$ & & $\begin{array}{r}0 \\
100\end{array}$ & & $\begin{array}{l}56 \\
44\end{array}$ \\
\hline Homocysteine & $17.8 \pm 7.7$ & & $17.8 \pm 8.2$ & \\
\hline Folate & $5.33 \pm 3.44$ & & $3.33 \pm 3.81^{*}$ & \\
\hline
\end{tabular}

${ }^{*}$ Indicates a significant difference from the control values $(P<0.05)$.

Table 2. Distribution of ACE G2350A genotypes and allele frequencies ( \pm standard errors) in the AMI patients and normal healthy subjects. Percentage values of genotypes are indicated in parentheses.

\begin{tabular}{lrc} 
Genotype & $\begin{array}{c}\text { AMI } \\
(n=207)\end{array}$ & $\begin{array}{c}\text { Normal healthy } \\
\text { subjects }(n=163)\end{array}$ \\
\hline GG & $110(53)$ & $85(52)$ \\
GA & $76(37)$ & $52(32)$ \\
AA & $21(10)$ & $26(16)$ \\
p (G allele) & $0.72 \pm 0.04$ & $0.68 \pm 0.04$ \\
q (A allele) & $0.28 \pm 0.04$ & $0.32 \pm 0.04$ \\
\hline
\end{tabular}

$57 \%$ were diabetic, while $19 \%$ were hypercholesterolemic. $26 \%$ of the patients had parental history of ischemic heart disease (IHD).

Among the controls, the mean age was $49.3 \pm 9.6$ years (range $31-70$ years). There were 123 males and 40 females and the mean BMI for this group was 24 \pm 5.6 which was quite close to the mean BMI of cases. $17 \%$ of the controls were smokers. $15 \%$ of the control subjects had parental history of IHD.

Table 2 shows the data pertaining to both genotype and allele distributions in the two groups of sub-
Table 3. Means $( \pm S . D$.) of age, BMI, plasma homocysteine and serum folate values according to ACE G2350A dimorphism in the overall sample population of this study.

\begin{tabular}{lcccc}
\hline \multicolumn{1}{c}{ Variable } & $\begin{array}{c}\text { GG } \\
(n=195)\end{array}$ & $\begin{array}{c}\text { GA } \\
(n=128)\end{array}$ & $\begin{array}{c}\text { AA } \\
(n=47)\end{array}$ & $*$ *value \\
\hline Age (years) & $50.1 \pm 9.4$ & $50.7 \pm 8.9$ & $51.5 \pm 8.9$ & 0.609 \\
BMI & $24.3 \pm 4.4$ & $24.5 \pm 4.3$ & $23.6 \pm 3.9$ & 0.471 \\
$\begin{array}{c}\text { Homocysteine } \\
(\mu \mathrm{mol} / \mathrm{l})\end{array}$ & $18.1 \pm 8.4$ & $17.8 \pm 8.2$ & $16.6 \pm 5.4$ & 0.52 \\
Folate $(\mathrm{ng} / \mathrm{ml})$ & $3.93 \pm 3.6$ & $3.84 \pm 3.1$ & $4.71 \pm 3.3$ & 0.2991 \\
\hline
\end{tabular}

${ }^{*} P$-value compares the mean values of the three genotypes for each variable by oneway ANOVA.

jects. ACE genotypes did not occur in Hardy-Weinberg proportions in the normal control group $\left(\chi^{2}=\right.$ $5.82,2$ degrees of freedom (df), $P=0.054)$ nor in AMI patients $\left(\chi^{2}=0.90,2 \mathrm{df}, P=0.64\right)$.

Differences in the distributions of the three genotypes according to clinical phenotype were not statistically significant (AMI vs Controls: $\chi^{2}=3.1,2 \mathrm{df}, P=0.217$ ). We also sought to explore association of $2350 \mathrm{G}$ $>$ A genotypes ( $G G, G A, A A$ ) with several phenotypic 
variables including age, BMI, serum folate and plasma homocysteine. There was no significant difference between the age and BMI profiles of the three genotypes (Table 3 ). The homocysteine and serum folate values were also not statistically different between genotypes (Table 3).

\section{Discussion}

Association (retrospective case-control) studies are influenced by the effects of selection bias, population stratification, confounding by other variables, and clinical criteria used to define patient groups. Minimizing the influence of the first two variables can be achieved by the exploration of putative associations in various ethnic groups that may be more genetically homogenous.

Pakistani people belong to an ethnic group which is relatively homogeneous and has the high rates of coronary artery disease CAD (McKeigue et al., 1988). Moreover, the relative risk of CAD in South Asian men is the highest at early ages (Balerajan, 1991; McKeigue, 1992). This points to an increased genetic predisposition of this population to the development of CAD.

"Control" individuals that were included in this investigation constituted a "comparison" rather than a "control" group. They were indeed free of disease, sex-matched with the patients, and had similar socioeconomic background to that of the patients. As these control individuals had no evidence of $\mathrm{MI}$, they represented a valid comparison group for these association studies, though it could not be predicted whether some of them would develop MI in future.

Several studies have suggested that the $D$ allele of ACE insertion/deletion (I/D) dimorphism confers increased risk for CVD (Cambien et al., 1992; 1994; Villard and Soubrier, 1996). At the same time, considerable negative evidence exists on this question. An analysis of 11,000 cases and controls showed no relationship between $\mathrm{MI}$ and the I/D polymorphism (Evan et al., 1994). The I/D marker was likewise not associated with $\mathrm{MI}$ in Italian and French sample populations (Arca et al., 1998; Ferrieres et al., 1999). O'Malley et al. (1999) summarized the association between the I/D polymorphism and CVD risk, grouping studies by geographical region and disease prevalence. In this analysis the ACE I/D polymorphism did not appear to be a clinically useful indicator of risk for MI. Zhu et al. (2001) reported 13 polymorphisms in the ACE gene using linkage and association studies. The polymorphism in exon 17, ACE G2350A had the most significant effect on plasma ACE concentration, accounting for $19 \%$ of the total variance in ACE plasma levels. After adjustment for the effect of ACE G2350A dimorphism, the I/D poly- morphism was no longer associated with plasma ACE concentration, indicating that it is in LD with $A C E$ G2350A and unlikely to be a functional mutation. Besides the effect on plasma ACE concentration, Zhu et al. (2001) reported that this dimorphism was significantly associated with SBP with an average increase of $3.2 \mathrm{mmHg}$ with each copy of the $G$ allele. These observations were suggestive of a possible role of ACE G2350A polymorphism in $\mathrm{MI}$.

We report the allele frequency of the ACE G2350A polymorphism in the Pakistani population to be $0.68 \pm$ 0.04 and $0.32 \pm 0.04$ for the $G 2350$ and $A 2350$ alleles respectively. In the present study, G2350A genotype distributions were not in Hardy-Weinberg proportions in the control group nor in the MI patient group. This may be a direct effect of consanguinity in this population.

Our data on the Pakistani population did not show any significant association between $\mathrm{G} 2350 \mathrm{~A}$ polymorphism and $\mathrm{MI}$. A recent study from our laboratory, reported a significant association between $\mathrm{G} 2350 \mathrm{~A}$ polymorphism and essential hypertension in Emirati population (Mahmood et al., 2003), indicating that this polymorphism may be the functional mutation of the $A C E$ gene. However, no association of G2350A polymorphism was found with $\mathrm{MI}$ in Emirati population. Hyperhomocysteinemia has been an established risk factor MI. A recent report by Westphal et al. indicated that ACE inhibitors increase the plasma levels of homocysteine in hypertensive patients, thereby compromising to some extent the cardio-protective function usually associated with them (2003). This was also suggestive of a possible interaction between $A C E$ gene expression and plasma level of homocysteine. Whether a polymorphic change in the ACE gene could have any influence on plasma homocysteine level is unknown, therefore, we investigated whether there is any association between plasma levels of homocysteine and ACE G2350A polymorphism. Although we found decreased levels of plasma homocysteine in AA genotype (Table 3), the value was not significantly different from the values in $G G$ and GA genotypes. This is suggestive of no association between any of the three genotypes and plasma levels of homocysteine. Similarly, no association was observed between any of these three genotypes and serum folate levels.

In summary, our data support that the G2350A dimorphism is neither associated with MI nor with plasma homocysteine or folate in the Pakistani population. Given the complex nature of genetic susceptibility for chronic degenerative diseases, further studies need to be conducted in individual ethnic groups to verify the disease relevance of this polymorphism. 


\section{Acknowledgement}

We gratefully acknowledge the technical help provided by Mr. Atif Ali, Ms. Farzana Abubakar, and Ms. Sadaf Riaz Sheikh.

\section{References}

Alhenc-Gelas F, Richard JL, Courbon D, Warnet JM, Corvol P. Distribution of plasma angiotensin I-converting enzyme levels in healthy men; relationship to environmental and hormonal parameters. J Lab Clin Med 1991;117:33-9

Arca M, Pannitteri G, Campagna F, Candeloro A, Montali A, Cantini R, Seccareccia F, Campa PP, Marino B, Ricci $G$. Angiotensin-converting enzyme gene polymorphism is associated with coronary atherosclerosis and myocardial infarction in a sample of Italian patients. Eur $\mathrm{J}$ Clin Invest 1998;28:485-90

Balarajan R. Ethnic differences in mortality from ischaemic heart disease and cerebrovascular disease in England and Wales. Br Med J 1991;302:560-4

Bohn M, Berge KE, Bakken A, ErikssenJ, Berg K. Insertion/ deletion (I/D) polymorphism at the locus for angiotensin I-converting enzyme and myocardial infarction. Clin Genet 1993; 44:292-7

Cambien F, Alhenc-Gelas F, Herbeth B, Andre JL, Rakotovao R, Gonzales MF, Allegrini J, Bloch C. Familial resemblance of plasma angiotensin-converting enzyme level: the Nancy Study. Am J Hum Genet 1988;43:774-80

Cambien F, Poirier O, Lecerf L, Evans A, Cambou JP, Arveiler D, Luc G, Bard JM, Bara L, Ricard S. Deletion polymorphism in the gene for angiotensin-converting enzyme is a potent risk factor for myocardial infarction. Nature 1992;359:641-4

Cambien F, Costerousse O, Tiret L, Poirier O, Lecerf L, Gonzales MF, Evans A, Arveiler D, Cambou JP, Luc G. Plasma level and gene polymorphism of angiotensinconverting enzyme in relation to myocardial infarction. Circulation 1994;90:669-76

Cambien F, Evans A. Angiotension l-converting enzyme gene polymorphism and coronary heart disease. Eur Heart J 1995;16:13-22

Ehlers MRW, Riordan JF. Angiotensin-converting enzyme: new concepts concerning its biological role. Biochemistry 1989;28:5311-8

Erdös EG, Skidgel RA. The angiotensin I-converting enzyme. Lab Invest 1987;56:345-8

Evans AE, Poirier O, Kee F, Lecerf L, McCrum E, Falconer T, Crane J, O' Rourke DF, Cambien F. Polymorphisms of the angiotensin-converting-enzyme gene in subjects who die from coronary heart disease. Q J Med 1994;87:211-4

Ferrieres J, Ruidavets JB, Fauvel J, Perret B, Taraszkiewicz D, Fourcade J, Nieto M, Chap H, Puel J. Angiotensin Iconverting enzyme gene polymorphism in a low-risk European population for coronary artery disease. Atherosclerosis 1999;142:211-6
Keavney B, McKenzie C, Parish S, Palmer A, Clark S, Youngman L, Delepine M, Lathrop M, Peto R, Collins R. Large-scale test of hypothesized associations between the angiotensin-converting-enzyme insertion/deletion polymorpohism and myocardial infarction in about 5000 cases and 6000 controls: International Studies of Infarct Survival (ISIS) Collaborators. Lancet 2000;355:434-42

Levy D, DeStefano AL, Larson MG, O' Donnell CJ, Lifton RP, Gavras H, Cupples AC, Myers RH. Evidence for a gene influencing blood pressure on chromosome 17:genome scan linkage results for longitudinal blood pressure phenotypes in subjects from The Framingham Heart Study. Hypertension 2000;36:477-83

Lindpaintner K, Pfeffer MA, Kreutz R, Stampfer MJ, Grodstein $\mathrm{F}$, LaMotte $\mathrm{F}$, Buring $\mathrm{J}$, Hennekens $\mathrm{CH}$. A prospective evaluation of an angiotensin-converting-enzyme gene polymorphism and the risk of ischemic heart disease. $\mathrm{N}$ Engl J Med 1995;332:706-11

Mahmood SM, Saboohi K, Ali OS, Bokhari AM, Siddiqui AA, Frossard pm. Association of the angiotensin-converting enzyme (ACE) gene G2350A dimorphism with essential hypertension. J Hum Hypertens 2003;17:719-23

McKeigue PM, Marmot MG. Mortality from coronary heart disease in Asian communities in London. $\mathrm{Br}$ Med $\mathrm{J}$ 1988; 297:903

McKeigue PM. Coronary heart disease in Indians, Pakistanis and Bangladeshis: Etiology and possibilities of prevention. $\mathrm{Br}$ Heart J 1992;67:341-2

McKenzie CA, Julier C, Forrester T, McFarlane-AndersonN, Keavney B, Lathrop GM, Ratcliffe PJ, Farrall M. Segregation and linkage analysis of serum angiotensin I-converting enzyme levels: evidence for two quantitative-trait loci. Am J Hum Genet 1995;57:1426-35

McKenzie CA, Abecasis GR, Keavney B, Forrester T, Ratcliffe PJ, Julier C, Connell JM, Bennett F, McFarlaneAnderson N, Lathrop GM, Cardon LR. Trans-ethnic fine mapping of a quantitative trait locus for circulating angiotensin I-converting enzyme (ACE). Hum Mol Genet 2001; 10:1077-84

O' Malley JP, Maslen CL, Illingworth DR. Angiotensinconverting enzyme and cardiovascular disease risk. Curr Opin Lipidol 1999;10:407-15

Rigat B, Hubert C, Alhenc-Gelas F, Cambien F, Corvol P, Soubrier $F$. An insertion/deletion polymorphism in the angiotensin-I-converting enzyme gene accounting for half the variance of serum enzyme levels. J Clin Invest 1990;86: 1343-6

Sambrook J, Fritsch EF, Maniatis T. Molecular cloning, a laboratory manual, 2ndEd, Cold Spring Harbour Laboratory Press, Cold Spring, NY

Soubrier F, Cambien F. The angiotensin l-converting enzyme gene polymorphism: implication in hypertension and myocardial infarction. Curr Opin Nephrol Hypertens 1994;3:25-9

Tiret L, Rigat B, Visvikis S, Breda C, Corvol P, Cambien $F$, Soubrier $F$. Evidence, from combined segregation and linkage analysis, that a variant of the angiotensin I-converting enzyme (ACE) gene controls plasma ACE levels. J Hum Genet 1992;51:197-205 
Villard E, Soubrier F. Molecular biology and genetics of the angiotensin I-converting enzyme: potential implications in cardiovascular diseases. Cardiovasc Res 1996;32:999-1007

Villard E, Tiret L, Visvikis S, Rakotovao R, Cambien F, Soubrier $F$. Identification of new polymorphisms of the angiotensin I-converting enzyme (ACE) gene, and study of their relationship to plasma ACE levels by two-QTL segregation linkage analysis. Am J Hum Genet 1996;58:1268-78

Westphal S, Rading A, Luley C, Dierkes J. Antihypertensive treatment and homocysteine concentrations. Metabolism
2003;52:261-3

Zhu X, McKenzie CA, Forrester T, Nickerson DA, Broeckel, U, Schunkert H., Doering A., Jacob HJ, Cooper RS, Rieder MJ. Localization of a small genomic region associated with elevated ACE. Am J Hum Genet 2000;67:1144-53

Zhu X, Bouzekri N, Southam L, Cooper RS, Adeyemo A, McKenzie CA, Luke A, Chen G, Elston RC, Ward R. Linkage and association analysis of angiotensin l-converting enzyme (ACE)-gene polymorphisms with ACE concentration and blood pressure. Am J Hum Genet 2001;68:1139-48 